\title{
ArcheoSciences
}

Revue d'archéométrie

33 (suppl.) | 2009

Mémoire du sol, espace des hommes

\section{Integrated examination and comparison of prospection methods at japanese historical Kiln sites}

Akihiro Kaneda, Yasushi Nishimura and Kazuhiko Nishiguchi

\section{(2) OpenEdition}

Journals

Electronic version

URL: https://journals.openedition.org/archeosciences/1343

DOI: 10.4000/archeosciences. 1343

ISBN: 978-2-7535-1599-4

ISSN: $2104-3728$

Publisher

Presses universitaires de Rennes

\section{Printed version}

Date of publication: 30 October 2009

Number of pages: 89-91

ISBN: 978-2-7535-0943-6

ISSN: $1960-1360$

\section{Electronic reference}

Akihiro Kaneda, Yasushi Nishimura and Kazuhiko Nishiguchi, "Integrated examination and comparison of prospection methods at japanese historical Kiln sites", ArcheoSciences [Online], 33 (suppl.) | 2009, Online since 30 October 2011, connection on 01 February 2022. URL: http://journals.openedition.org/ archeosciences/1343; DOI: https://doi.org/10.4000/archeosciences.1343 


\title{
Integrated examination and comparison of prospection methods at japanese historical Kiln sites
}

\author{
Akihiro KanedA*, Yasushi Nishimura*, Kazuhiko Nishiguchi*
}

Key words: GIS, GPR, Magnetometer, Resistivity, Kiln site.

\begin{abstract}
Magnetic prospection in Japan has been used widely for surveying archaeological sites with thermoremanent magnetism. Kiln sites are a good target and much data has already been accumulated over a long period of time. Magnetic anomalies are two-dimensional, however, while many archaeologists today require three-dimensional data in order to be able to plan for the excavation and preservation of a kiln site.

Our group has therefore examined in detail how kiln type can be assessed by archaeological prospection methods. GIS has proved effective for the integration of such information. It provides a useful understanding of archaeological sites. This presentation concerns archaeological prospection results and examination of kiln sites in recent years.

The Samukaze kiln site in Setouchi City (Okayama Prefecture) is famous for its Sue ware (Japanese ancient unglazed stoneware). It is composed of several tunnel kilns dating mainly to between the 7 th and 8 th centuries. An archaeological prospection was carried out in 2004 and 2005, aiming at a detailed acquisition of information by various prospection methods put to work in the same place. A fluxgate magnetometer, Proton magnetometer, GPR and resistivity meter were used for this project.

The results demonstrated differences when different prospection methods, such as GPR and magnetic method, were
\end{abstract}

compared. For example, a reflection of a circle exists in the shallow part and the kiln body appears under that. This reflection of a circle was not detected in the magnetic result, meaning it was not related to the kiln.

Archaeological excavation carried out in the winter of 2005, following the prospection, revealed that a hole exists in the upper part of the kiln. A large amount of damaged pottery and pieces of kiln wall were found abandoned in the hole. The kiln was confirmed underneath and we were able to compare the results of our prospection.

The Kawarazuka kiln sites in Ishioka City (Ibaragi Prefecture) produced roof tiles in the 8th-9th century AD, supplying the Hitachi-kokuhu site(ancient local government building) and the Hitachi-Kokubunji temple. Having made a microtopographical map of the site, we carried out archaeological prospection in 2007-2008. The fluxgate magnetometer, Proton magnetometer, GPR and resistivity meter were used for this project.

The prospection results were examined against the microtopographical map, demonstrating that GIS overlies the GPR and magnetometer results. They have also shown a separate part where a kiln might exist.

The Naeshirogawa kiln sites in Hioki City (Kagoshima Prefecture) are famous for the early-modern Satsuma ware (one of the ceramics in Japan). They were important for

* Nara National Cultural Properties Research Institute. (akaneda@nabunken.go.jp) 


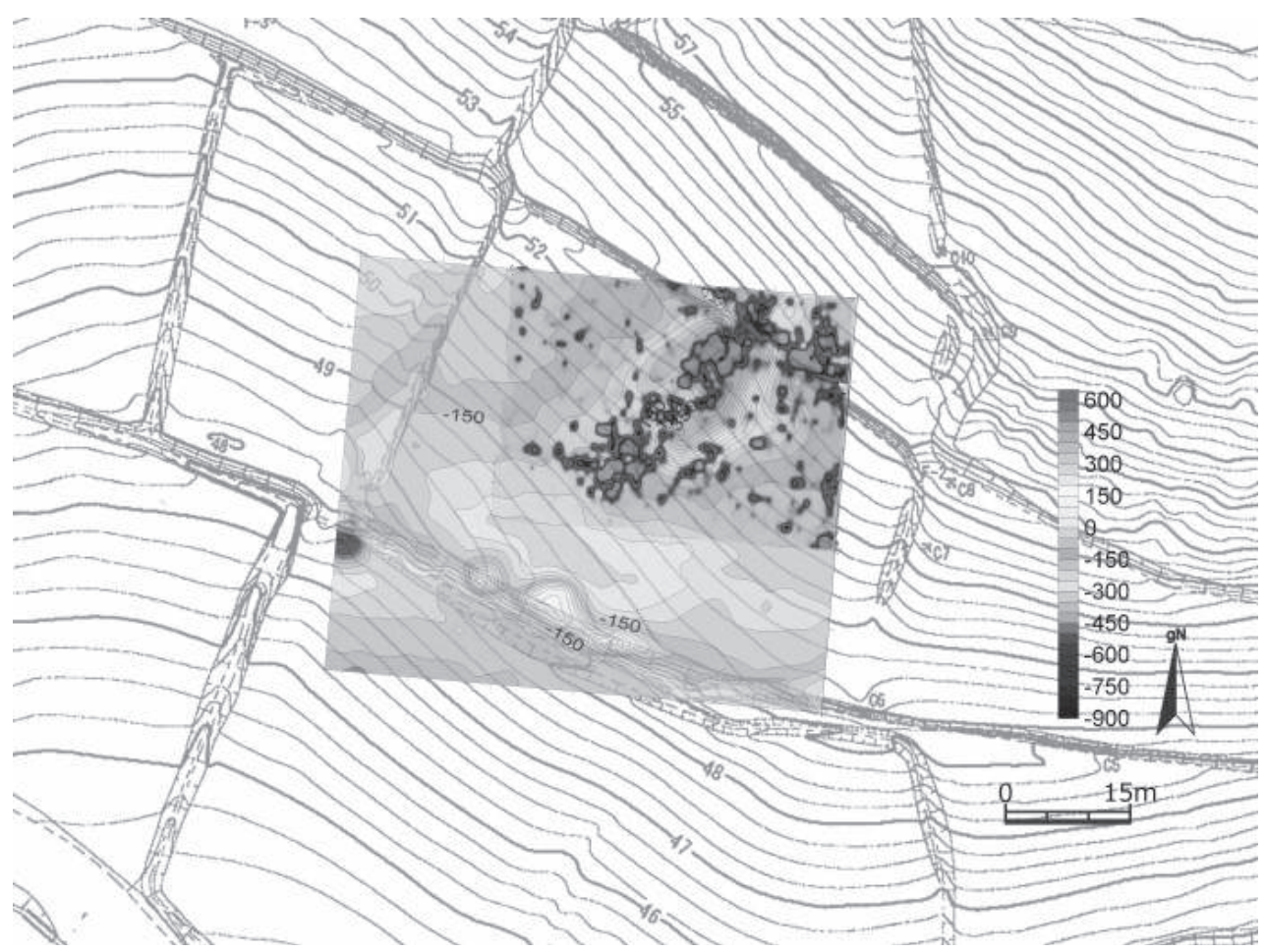

Figure 1

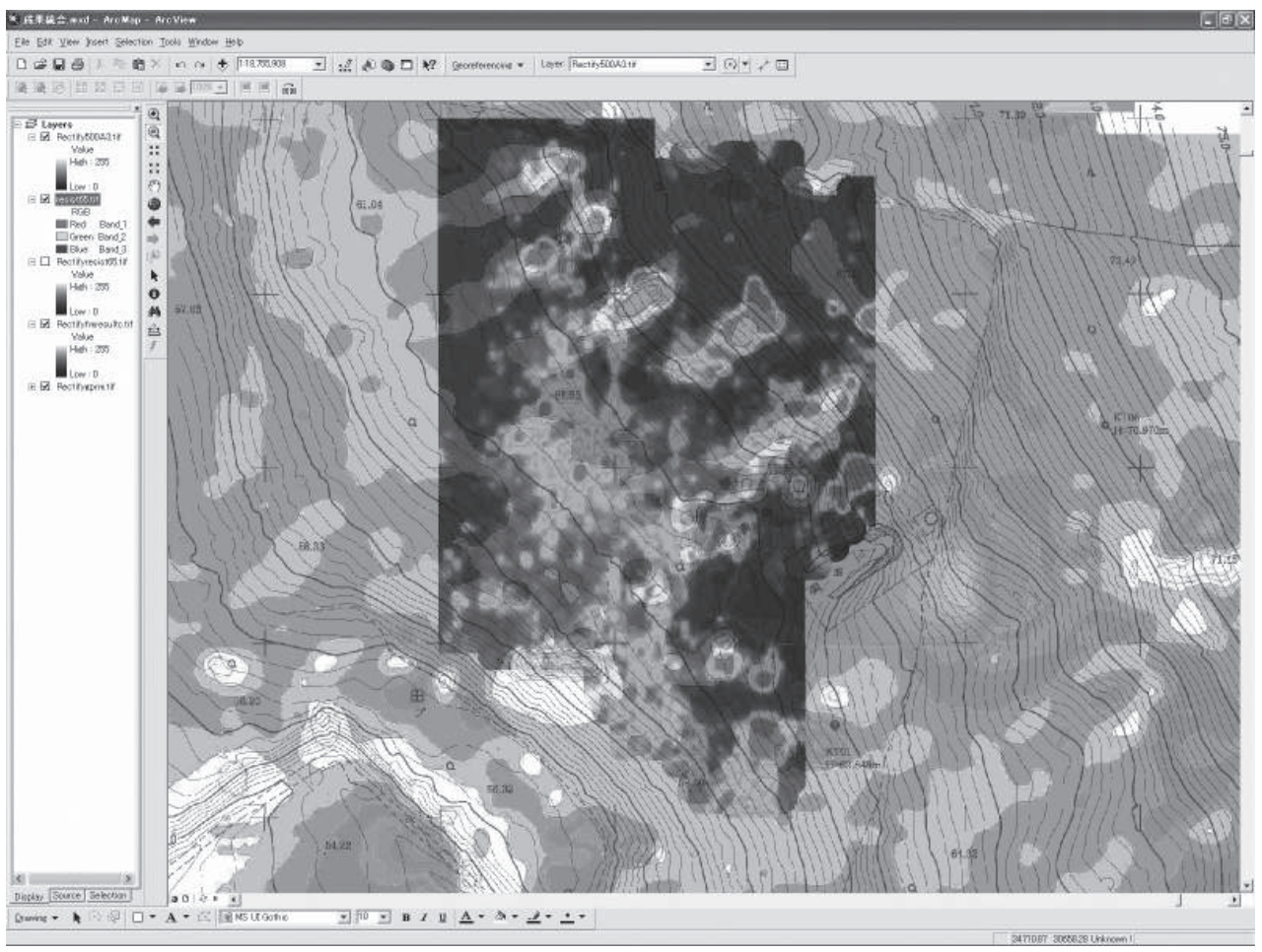

Figure 2 
Figure 3

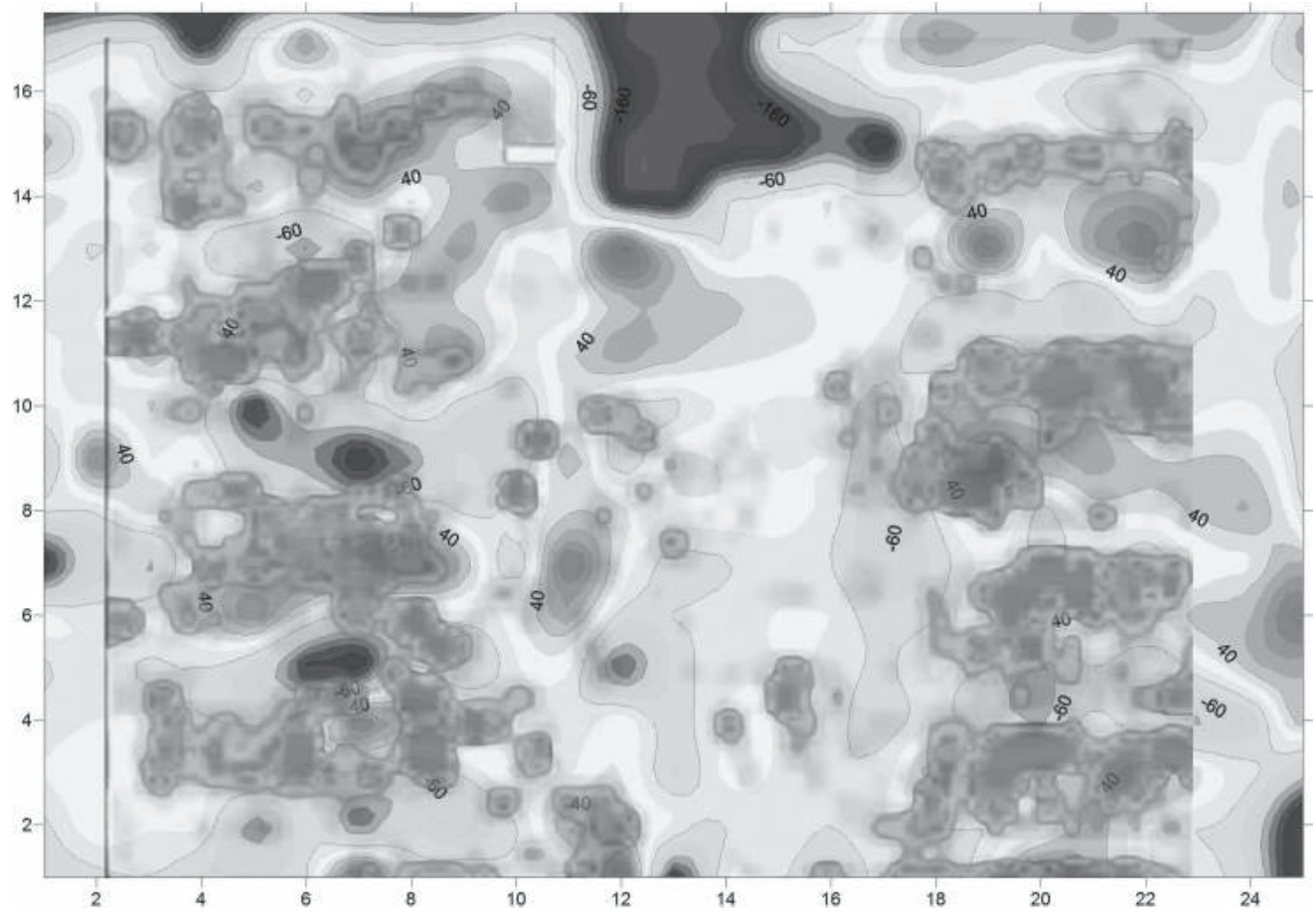

research into the history of Satsuma ware and modern ceramic production systems.

Kagoshima University has been researching the distribution and location of kilns since 2006. In 2008, Kagoshima University and our organization carried out archaeological prospection of confirmed and presumed sites. The fluxgate magnetometer and GPR were used for this project.

The surveys made it possible to confirm a presumed site without having to excavate and they have also made it easier to determine which of the two types of kiln the site represents: either single- or multiple-chambered climbing kiln. This has already been recognized at the Bizen Minami Ogama kiln sites(Okayama Prefecture).

The practice is far from established yet. There are many problems. For instance, what is the threshold in overlay setting? Is it possible to integrate into a more advanced method? We will try to deal with these issues.

\section{References}

Witten, A. J., 2006. Geophysics and Archaeology. Equinox Publishing. UK.

Gaffney, C. and Gater, J., 2003. Revealing the Buried Past. Tempus. UK.

Nishimura, Y., 2001. Archaeological Prospection. Japanese Art, 422. Shibundo. Japan (in Japanese). 